\title{
PEMBANGUNAN MANUSIA UNTUK MEWUJUDKAN MASYARAKAT KALIMANTAN TIMUR BERKUALITAS ${ }^{1}$
}

\author{
Suripto \\ Peneliti Muda Pusat Kajian Kinerja Kelembagaan - \\ Lembaga Administrasi Negara \\ Jl. Veteran No. 10 Jakarta Pusat \\ Email : suripto3x@rocketmail.com atau rivto76@yahoo.co.id
}

\begin{abstract}
East Kalimantan is one of the provinces in Indonesia with the best Human Development Index. This is indicated by achieving fifth rank nationally for the last four years. It is certainly very interesting to find out various things in human development in East Kalimantan by the achievement it has. This study aims to measure the level of efficiency and quality of human development in East Kalimantan. The evaluation method used in this study is literature study. The evaluation uses two approaches namely the evaluation of the series and evaluation of given years. The tools used in data analyzing is Data Envelopment Analysis (DEA) DEA-Solver model LV3.0/CCR (CCR-O) / (CCR-I) and DEASolver LV3.0 / Window (Window-OC). The result of the analysis from both models shows that human development has been streamlined.
\end{abstract}

Keywords: East Kalimantan, Education, Health, Economy, GDP, Evaluation.

\section{Intisari}

Kalimantan Timur (Kaltim) merupakan salah satu provinsi di Indonesia dengan Index Pembangunan Manusia terbaik. Hal tersebut ditunjukan dengan peringkat 5 nasional selama 4 tahun terakhir. Dengan prestasi tersebut tentunya sangat menarik untuk mengetahui berbagai hal dalam pembangunan manusia di Kaltim. Study ini bertujuan mengukur tingkat efisiensi dan kualitas pembangunanan manusia Kaltim. Selanjuntya, metode yang digunakan adalah evaluasi dengan study kepustakaan. Dalam melakukan evaluasi menggunakan dua pendekatan yakni evaluasi tahun seri dan evaluasi tahun tertentu. Alat bantu analisis yang digunakan Data Envelopment Analysis (DEA) dengan model DEASolver LV3.0/CCR (CCR-O)/(CCR-I) dan DEA-Solver LV3.0/ Window(Window-O-C). Hasil analisis kedua model tersebut menunjukan pembangunan manusia telah efisien.

Kata Kunci : Kaltim, Pendidikan, Kesehatan, Ekonomi, PDRB, Evaluasi.

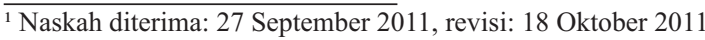




\section{A. PENDAHULUAN}

Visi Provinsi Kalimantan Timur (Kaltim) adalah "Mewujudkan Kalimantan Timur Sebagai Pusat Agroindustri dan Energi Terkemuka Menuju Masyarakat Adil dan Sejahtera". ${ }^{2}$ Untuk mewujudkannya didasarkan dengan tiga modal bangsa meliputi modal manusia, modal alam dan fisik serta modal sosial. Modal manusia memfokuskan untuk mewujudkan kehidupan masyarakat yang berkualitas dan bebas kemiskinan. Modal alam dan fisik dengan memanfaatkan kekayaan alam secara optimal dan berkelanjutan. Dan, modal sosial dengan mewujudkan sinergi kelompok birokrasi wirausaha dan pekerja menuju daya saing global. Visi tersebut dijabarkan dalam tujuh misi yang tercermin dalam sepuluh agenda pembangunan meliputi kemandirian dan kedaulatan pangan; pengentasan kemiskinan; pengangguran; keterbatasan akses p e rmodalan; reform a s i birokrasi/pelayanan publik; degradasi mutu lingkungan; daya saing \& iklim investasi; pendidikan \& pelayanan kesehatan; infrastruktur; pembangunan perbatasan, pedalaman \& daerah tertiggal. Selanjuntya dalam Rencana Pembangununan Jangka Menengah Daerah (RPJMD) Provinsi Kalimantan Timur 2009 - 2014 juga dijabarkan tujuh prioritas pembangunan Provinsi Kaltim. Pembangunan manusia diantaranya meningkatkan kesejahteraan masyarakat perbatasan, meningkatkan kualitas sumber daya manusia, peningkatan ekonomi masyarakat dan penurunan tingkat kemiskinan.

Kaltim merupakan salah satu provinsi dengan prestasi terbaik dalam Indeks Pembangunan Manusia (IPM) secara nasional. Berdasarkan Data Badan Pusat Statistik (BPS) Kaltim dan Pusat, IPM Kaltim selalu mengalami peningkatan indeks, tahun 2007 dengan nilai 73,77, tahun 2008 sebesar 74,52 dan pada tahun 2009 mencapai $75,11 .^{3}$ Dengan nilai indeks tersebut menempatkan Provinsi Kaltim pada peringkat lima secara nasional. Perkembangan variabel IPM Provinsi Kaltim 2007 - 2009 seperti pada Tabel 1.

Tabel 1. Perkembangan Variabel IPM Provinsi Kaltim 2007 - 2009

\begin{tabular}{|c|c|c|c|c|c|c|}
\hline \multirow[b]{3}{*}{ Tahun } & \multirow[b]{3}{*}{ IPM } & \multicolumn{4}{|c|}{ Variabel } & \multirow[b]{3}{*}{$\begin{array}{c}\text { Daya Beli } \\
\text { Reduksi } \\
\text { Shortfall IPM }\end{array}$} \\
\hline & & \multicolumn{2}{|c|}{ Pendidikan } & \multirow{2}{*}{$\begin{array}{c}\text { Kesehatan } \\
\text { Rata-Rata Angka } \\
\text { Harapan Hidup } \\
\text { (tahun) }\end{array}$} & \multirow{2}{*}{$\begin{array}{c}\text { Daya Beli } \\
\text { Rata-rata } \\
\text { Pengeluaran Per } \\
\text { Kapita (Rp. 000) }\end{array}$} & \\
\hline & & $\begin{array}{c}\text { Angka } \\
\text { Melek } \\
\text { Huruf (\%) }\end{array}$ & $\begin{array}{l}\text { Rata-Rata Lama } \\
\text { Sekolah (tahun) }\end{array}$ & & & \\
\hline$(1)$ & $(2)$ & (3) & $(4)$ & $(5)$ & $(6)$ & $(7)$ \\
\hline 2006 & 73,30 & 95,50 & 8,80 & 70,40 & 623,60 & 1,87 \\
\hline 2007 & 73,77 & 95,70 & 8,60 & 70,60 & 628,10 & 1,91 \\
\hline 2008 & 74,52 & 96,36 & 8,80 & 70,80 & 634,52 & 2,87 \\
\hline 2009 & 75,11 & 96,86 & 8,85 & 71,00 & 638,73 & 2,32 \\
\hline
\end{tabular}

Sumber : Badan Pusat Statistik Provinsi Kalimantan Timur dan BPS Pusat

\footnotetext{
${ }^{2}$ Rencana Pembangununan Jangka Menengah Daerah Provinsi Kalimantan Timur 2009 - 2014

${ }^{3}$ Ibid
} 
Prestasi tersebut tentunya tidak terlepas dari komitmen dalam membangun variabel-variabel IPM semakin baik. Pembangunan variabel pendidikan dan kesehatan meliputi sarana fisik dan non sarana fisik. Sarana fisik antara lain membangun gedung sekolah dan penunjangnya, rumah sakit, klinik, puskesmas. Sedangkan, pembangunan non fisik antara lain penambahan jumlah tenaga pendidik, tenaga kesehatan dan peningkatan kualitasnya. Pembangunan infrastruktur pendidikan telah meningkatkan prosentase angka melek huruf dan rata-rata lama sekolah (lihat Tabel 1). Begitu juga, pembangunan infrastruktur kesehatan telah meningkatkan rata-rata harapan hidup manusia (lihat Tabel 1). Selanjutnya, pembangunan variabel daya beli dilakukan dengan pembangunan infrastruktur perhubungan antara lain jalan, jembatan, dermaga, terminal dan lainnya. Pembangunan variabel ini memberikan kelancaran ekonomi antar daerah yang memberikan dampak pada peningkatan pendapatan perkapita penduduk Provinsi Kaltim. Pendapatan per kapita non migas pada tahun 2007 sebesar Rp. 11.468.786,- tahun 2008 meningkat Rp. 15.314.394,- dan tahun 2009 mencapai Rp. 17.885.831,-.

Variabel daya beli merupakan kontributor terbesar dalam pembangunan manusia di Kaltim selama tahun 2006 - 2009 sebesar Rp. $2,42 \%$ yang diikuti oleh variabel pendidikan sebesar $0.85 \%$ dan kesehatan sebesar 0,57 \%. Data tersebut menunjukan bahwa pada periode tersebut, Kaltim lebih memprioritaskan pembangunan ekonomi. Hal ini tentunya ditunjukan pertumbuhan ekonomi tanpa migas yang relative tinggi yakni sebesar 6,34 $\%$ pada tahun 2008 dan $6,59 \%$ pada tahun 2009. ${ }^{4}$ Untuk mempertahankan prestasi tersebut tentunya perlu dipertahankan hal yang telah baik dan ditingkatkan pada variabel yang belum optimal.

Prestasi IPM Kaltim merupakan sumbangan keberhasilan pembangunan manusia pemerintah daerah kabupaten dan kota di Provinsi Kaltim. Nilai IPM kabupaten dan kota tahun 2002 - 2009 seperti pada Grafik 1.

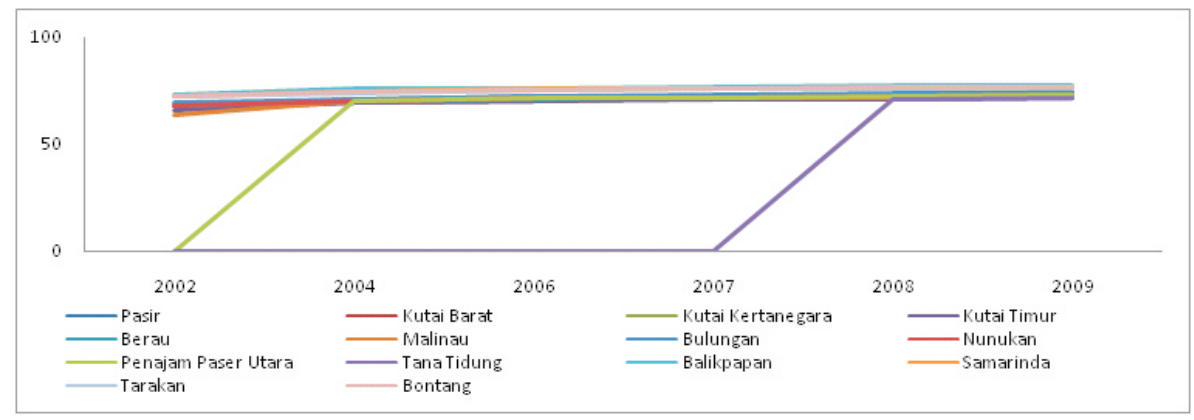

Sumber : Kondisi Sosial Ekonomi dan Indikator Penting Kalimantan Timur Edisi Januari 2011 Grafik 1 : Perkembangan IPM kabupaten/kota di Provinsi Kaltim

${ }^{4}$ Ringkasan Data Indikator Penting Pembangunan Kaltim - Informasi Data Tahun 2010-2011 - PDRB dan Pertumbuhan Ekonomi hal. 35 
Grafik 1 menunjukan bahwa dalam periode 2002 - 2009, Kota Balikpapan selalu menempati peringkat teratas dan Kabupaten Kutai Timur sebagai yang terendah di Provinsi Kaltim. Tetapi apabila dilihat perkembangan indeks dari tahun ke tahun maka periode 2006 - 2007, Kabupaten Berau menempati point terbesar (1.00) dan Kabupaten Kutai Kartanegara dengan point terkecil (0.10). Periode 2007 - 2008, Kabupaten Kutai Barat sebagai peraih peningkatan point terbesar (1.16) dan terendah (0.08) ditempati Kabupaten Malinau. Kemudian pada periode 2008 - 2009, peningkatan point tertinggi diraih oleh Kabupaten Tana Tindung (0.76) dan nilai terendah di Kota Balikpapan (0.18). Dan, jika dilihat dengan periode 2006 - 2009 maka Kabupaten Bulungan yang menikmati peningkatan tertinggi (2.17) dan Kabupaten Malinau sebagai yang terendah (0.86). Perkembangan IPM dari waktu ke waktu tersebut menunjukan upaya yang dilakukan oleh Kabupaten/Kota di Provinsi Kaltim dalam pembangunan manusia. Upaya-upaya tersebut tercermin dari kebijakan dan pelaksanaannya, selain itu juga dapat terlihat bagaimana komitmen dan konsisten kebijakan pembangunan pada periode tertentu. Sebagai contoh. Kabupaten Bulungan memiliki peningkatan paling tinggi pada peride 2006 - 2009, jika dilihat dengan periode tahunan maka pada 2006 - 2008 memiliki pertumbuhan tinggi (0.80 dan 1.00) dibandingkan dengan kabupaten/kota lainnya. Tetapi, pada periode 2008-2009 hanya mengalami peningkatan 0.37 atau relatif rendah dibandingkan dengan lainnya yang rata-rata diatas 0.40 .

Nilai dan data tersebut diatas tentunya memiliki makna dalam pembangunan manusia di wilayah Kaltim. Sehingga sangat menarik untuk mengetahui faktor-faktor yang mempengaruhi nilai tersebut. Selanjuntya, pertanyaan kajiannya adalah Bagaimana tingkat efisiensi pembangunan manusia di Kaltim? Bagaimana kualitas (pemerataan) pembangunan manusia di kabupaten/kota di Provinsi Kaltim? Apa dan bagaimana kebijakan pemerintah daerah meningkatkan IPM dengan kebijakan pendidikan, kesehatan dan kemampuan daya beli masyarakat? Dengan pertanyaan tersebut, maka tujuan study ini adalah mengukur tingkat efisiensi serta kualitas pembangunan manusia di Kaltim. Studi ini tentunya lebih mendalam jika dibandingkan dengan kajian/penelitian Pembangunan Manusia Provinsi Kalimantan Timur sebelumnya yang dilakukan oleh Yulfita Raharjo, Daliyo dan Suko Bandiyono. Penelitian tersebut memiliki tujuan utama membuat IPM Provinsi Kaltim yang dapat $m$ e $n$ g g a m b a $r k$ a $n$ perkembangan/perubahannya, ditingkat provinsi sampai DATI II dalam kurun waktu sepuluh tahun terakhir ini (1980-1990) dengan tiga komponen kesehatan, pendidikan dan pendapatan perkapita.

Prosiding Seminar Evaluasi Hasil Kegiatan Litbang LIPI di Kalimantan Timur Pelita V : Pembangunan Manusia Provinsi Kalimantan Timur : Yulfita Raharjo, Daliyo dan Suko Bandiyono sumber

elib.pdii.lipi.go.id/katalog/index.php/searchkatalog/.../1431.pdf diakeses tanggal 17 Oktober 2011 


\section{B. KONSEP IPM}

Tujuan akhir dari pembangunan adalah kesejahteraan masyarakat. Banyak teori, metode yang dapat digunakan sebagai alat untuk mengukur keberhasilan pembangunan. Salah satunya adalah pembangunan manusia dalam suatu wilayah. Wilayah tersebut antara lain Negara, provinsi, kabupaten, kecamatan dan lain sebagainya. Pengukuran keberhasilan pembangunan manusia antara lain dapat menggunakan perhitungan Indeks Pembangunan Manusia. Hasil konggres pembangunan manusia Indonesia telah menghasilkan dokumen permufakatan pembangunan manusia Indonesia menuju Indoneisa yang lebih sejahtera, adil, dan makmur, piagam pembangunan manusia Indonesia, dan

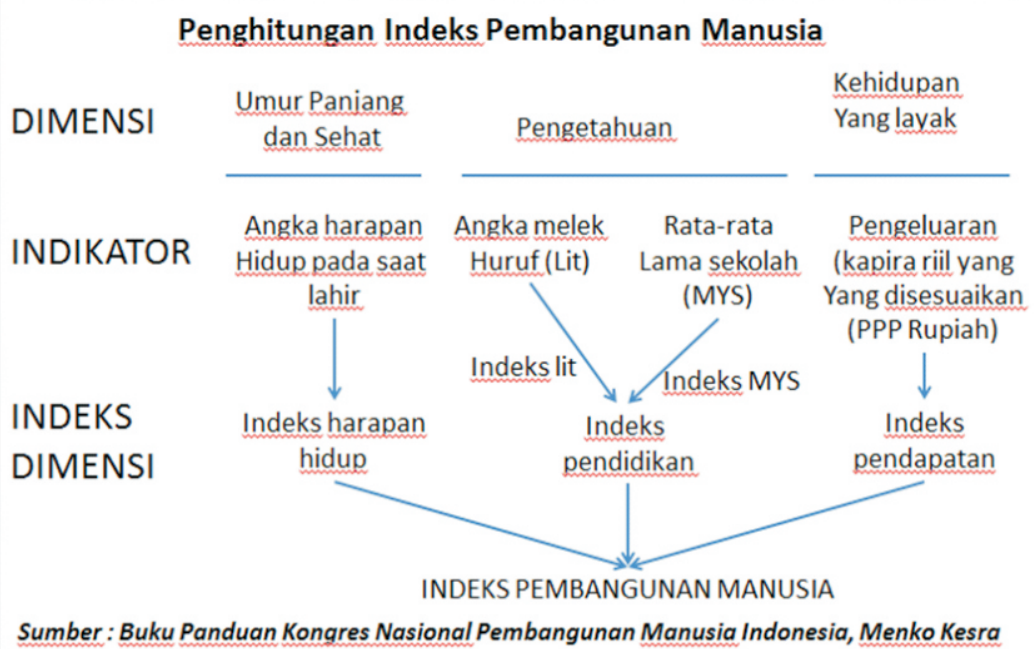
dan TKPK, 2006

Gambar 2 : Penghitungan Indeks Pembangunan Manusia

Pengukuran IPM menggunakan tiga variabel yaitu meliputi :

- Variabel Harapan Hidup

Variabel ini diukur dengan angka harapan hidup ketika lahir. Variabel tersebut dapat dilihat dari status kesehatannya, dimana tingkat kesehatan dapat mempengaruhi usia harapan hidup. Sehingga sangat penting untuk mengukur atau pengevaluasi pembangunan kesehatan suatu daerah/negara.
- Variabel pendidikan Variabel pendidikan diukur dengan rata-rata lama sekolah dan angka melek huruf penduduk usia 15 tahun ke atas. Pendidikan merupakan variabel yang sangat penting untuk mengetahui tingkat pengetahuan dan keterampilan penduduknya. $\mathrm{O} 1 \mathrm{e} \mathrm{h} \mathrm{k}$ a r e n a i $\mathrm{t} \mathrm{u}$, Pencapaian/keberhasilan variabel pendidikan dapat dilihat dari pembangunan pendidikannya 
antara lain meliputi penyediaan sarana pendidikan seperti kelas dan sekolah, jumlah guru, jumlah siswa, angka anak tidak sekolah dan lain sebagainya.

- Variabel Pendapatan Variabel ini diukur dengan pendapatan per kapita yang mempengaruhi kemampuan daya beli. Pendapatan perkapita tentunya akan sangat dipengaruhi oleh angka pengangguran pada suatu daerah/negara. Sehingga, dalam variabel pendapatan juga akan melihat pembangunan dalam bidang ekonomi atau kebijakan dalam memberdayakan ekonomi masyarakat. Selanjutnya, Perhitungan IPM menggunakan tiga variabel seperti pada Gambar 2. Nilai (skore) dari IPM adalah 0 100 .

\section{METOdOLOGI}

Paper ini menggunakan metode evaluasi post test dengan study kepustakaan. Evaluasi sebagai salah satu tahapan penting dalam manajemen bertujuan memberikan penilaian terhadap sesuatu. Pemilihan metode tersebut tentunya tidak terlepas dari dua alasan penting pertama sifat data yang digunakan telah selesai pelaksananya atau menjadi hasil akhir. Kedua, data yang digunakan merupakan data sekunder antara lain Kalimatan Timur Dalam Angka tahun 2010 dan 2009, Kondisi Sosial ekonomi dan Indikator Penting Kalimantan Timur, Kajian Ekonomi Regional. Kemudian untuk memberikan penguatan hasil analisa digunakan referensi pendukungnya antara lain website resmi Provinsi Kalimantan Timur dan kabupaten/kota didalamnya. Website resmi Badan Pusat Statistik Provinsi Kaltim dan nasional, dan lain sebagainya.

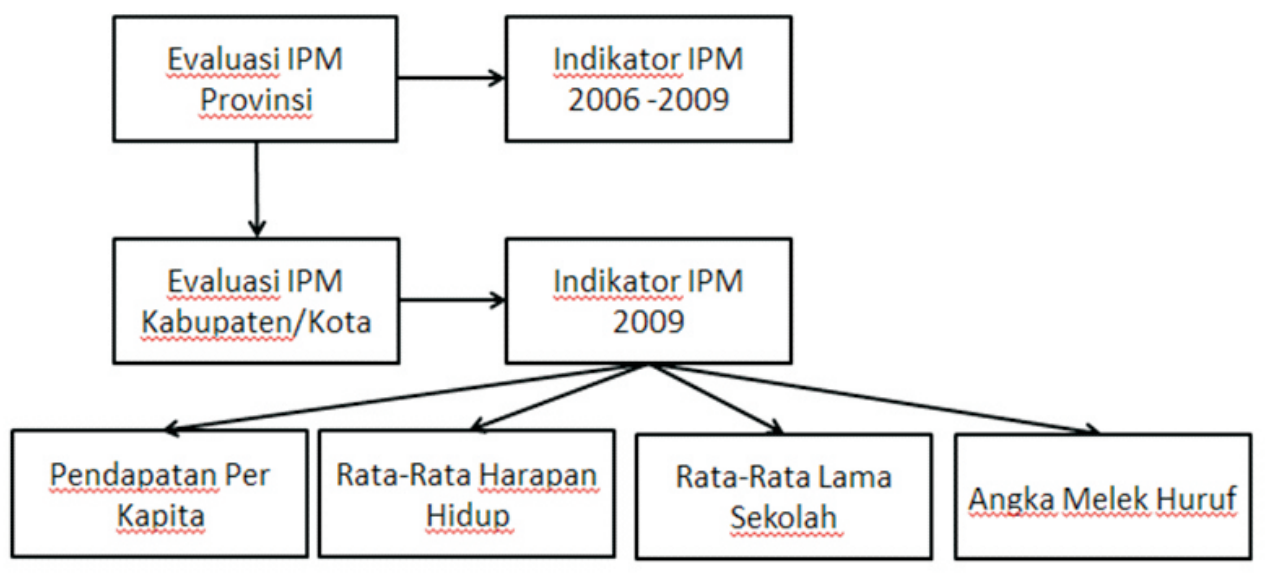

Gambar 3 : Tahapan Evaluasi IPM Provinsi Kaltim 
Selanjutnya, evaluasi dilakukan dengan tiga tahap meliputi evaluasi IPM provinsi, evaluasi IPM Kabupaten Kota dan Evaluasi Variabel IPM. Alur evaluasi seperti pada Gambar 3. Tahap pertama dilakukan untuk mengetahui nilai efisiensi IPM pada tahun 2006 2009. Sehingga demikian, akan dapat dilihat tahun yang telah optimal dan tahun yang belum optimal. Tahap dua dilakukan untuk mengetahui nilai efisiensi dari setiap Kabupaten/Kota dalam pembangunan manusia. Pada tahap ini digunakan data tahun 2009. Sedangkan tahap ketiga melakukan evaluasi dari masing-masing indikator IPM Provinsi, Kabupaten/Kota. Indikator evaluasi merujuk hasil konggres pembangunan manusia Indonesia 2006 sebagai indikator baku yang telah disepakati dalam mengukur keberhasilan pembangunan manusia di Indonesia. Selain itu, tahap ke tiga juga menggali kebijakan yang ditempuh oleh masing-masing pemerintah daerah dalam membangun manusia.

A na 1 is is a evaluas i pembangunan manusia Provinsi Kaltim menggunakan alat bantu Data Envelopment Analysis (DEA). DEA merupakan alat yang dirancang dan dibangun untuk mengukur tingkat efisiensi relatif Decision Making Unit (DMU) dengan membandingkan antara input dan output. Penentuan penilaian efisien dari suatu DMU ditentukan dengan capaian nilai 1 (satu) atau dengan pembulatannya. Oleh karena itu, DMU yang belum mencapai angka 1 (satu) dikatakan relatif belum efisien. DEA memiliki banyak keuntungan antara lain dapat mengukur banyak variabel input dan output yang memilki satuan pengukuran berbeda. Study ini menggunakan Software DEA dengan model DEA-Solver LV3.0/CCR (CCRO)/(CCR-I) dan DEA-Solver LV3.0/Window (Window-O-C).

DMU dalam study ini meliputi Paser (Pr), Kutai Barat (KB), Kutai Kartanegara (KK), Kutai Timur (KT), Berau (Br), Malinau (Mln), Bulungan (Blg), Nunukan (Nn), Penajam Paser Utara (PPU), Tana Tidung (TT), Balik Papan (BP), Samarinda (Smd), Tarakan (Tn) dan Bontang (Btg). Selanjuntya, yang digunakan menjadi indikator input meliputi angka melek huruf (AHH), Rata-rata lama sekolah (LS), rata-rata harapan hidup $(\mathrm{HH})$ dan pendapatan per kapita (PPK).

\section{DATA PEMBA N G U N N MANUSIA}

IPM Provinsi Kaltim 2007 2009 ditinjau dari nilai variabel pendidikan, kesehatan dan daya beli seperti pada Tabel 1. Kemudian, perkembangan IPM kabupaten/kota tahun 2002-2009 dapat dilihat pada Grafik 1. Selanjutnya, Variabel IPM kabupaten/kota di Provinsi Kaltim pada tahun 2009 pada Tabel 2.

${ }_{7}^{7}$ Proceding : 2011, Suripto, Best practice efisiensi pembangunan bidang kesehatan provinsi kalimantan timur 
Tabel 2 : Nilai Variabel IPM Tahun 2009

\begin{tabular}{lrrrrr}
\hline DMU & IPM & AMH & LS & HH & PPK \\
\hline$(1)$ & $(2)$ & $(3)$ & $(4)$ & $(5)$ & $(6)$ \\
\hline Pr & 73.99 & 95.22 & 7.80 & 72.74 & 626.47 \\
KB & 72.66 & 95.97 & 7.86 & 70.08 & 625.57 \\
KK & 72.54 & 96.87 & 8.38 & 67.85 & 632.64 \\
KT & 71.27 & 95.89 & 7.70 & 68.43 & 621.34 \\
Br & 73.17 & 96.05 & 8.03 & 69.66 & 633.47 \\
Mln & 72.36 & 92.65 & 7.75 & 68.22 & 645.91 \\
Blg & 74.67 & 95.51 & 7.88 & 72.73 & 633.85 \\
Nn & 73.38 & 93.41 & 7.45 & 71.30 & 637.56 \\
PPU & 73.18 & 94.47 & 7.60 & 71.32 & 630.25 \\
TT & 71.44 & 88.01 & 7.70 & 72.61 & 616.13 \\
BP & 77.49 & 98.35 & 10.08 & 71.95 & 646.65 \\
Smd & 76.45 & 97.91 & 9.77 & 71.01 & 644.22 \\
Tn & 76.32 & 97.90 & 9.37 & 71.55 & 642.45 \\
Btg & 76.32 & 98.35 & 10.07 & 72.26 & 629.41 \\
\hline Sumbr & & & & & \\
\hline
\end{tabular}

Sumber : Kondisi Sosial Ekonomi dan Indikator Penting Kalimantan Timur Edisi Januari 2011

Tabel 2 menunjukan bahwa 4 (empat) DMU kota memiliki nilai IPM diatas nilai IPM provinsi meliputi BP, Smd, Tn dan Btg. Sedangkan jika dibandingkan dengan IPM nacional maka hanya terdapat 2 (dua) DMU yang berada dibawah nilai nasional (71.76) meliputi KT dan TT. Sedangkan, DMU lainnya memiliki nilai diatas nilai IPM Nasional.

\section{E. PEMBAHASAN}

Dalam melakukan analisa pembangunan manusia di Provinsi Kaltim dibagi menjadi 3 bagian yaitu Analisa IPM Regional, Analisa IPM Kabupaten/Kota dan Analisa Kebijakan Pembangunan Manusia.

\section{Analisis IPM Regional}

Analisis IPM Regional menggunakan data IPM tahun seri selama 2006 -2009 (lihat Tabel 1). Hasil Analisa dengan menggunakan DEA-Solver LV3.0/ CCR(CCR-O) atau DEA-Solver LV3.0/ Window (Window-O-C) menunjukan bahwa pembangunan IPM di Kaltim selama tahun 2006-2009 telah sangat efisien.
Hal ini ditunjukan dengan pencapaian nilai 1.00 (satu) pada setiap tahunnya. Nilai tersebut menunjukan bahwa pembangunan Provinsi Kaltim dalam bidang pendidikan, kesehatan dan ekonomi telah diselenggarakan secara optimal. Artinya, pembangunan dalam bidang pendidikan, kesehatan dan ekonomi telah sesuai dengan capaian IPM-nya.

Nilai sangat efisien tersebut tentunya sangat menarik untuk dibahas lebih mendalam. Oleh karena itu, pembahasan selanjutnya akan melihat perkembangan pembangunan bidang pendidikan, kesehatan dan ekonomi.

\section{Pembangunan bidang pendidikan}

Provinsi Kaltim telah menetapkan visi dalam bidang pendidikan "Terwujudnya SDM Kaltim yang bertaqwa, unggul dan berbudaya melalui pembinaan dan pengembangan pendidikan yang bermutu dan berkeadilan". Kemudian, untuk mencapainya menyelenggarakan misi sebagai berikut :

- Meningkatkan pendidikan dan 
pengamalan ajaran agama dalam kehidupan sehari-hari untuk mewujudkan kualitas keimanan dan ketaqwaan kepada Tuhan Yang Maha Esa.

- Membina mutu dan relevansi pendidikan.

- Meningkatkan manajemen pendidikan.

- Membina dan mengembangkan generasi muda, olahraga, bahasa, seni, dan budaya.

Penetapan visi dan misi tersebut merupakan langkah penting untuk menentukan arah pendidikan. Jika hal pembangunan pendidikan ditimbang dengan visi dan misi, maka Provinsi Kaltim telah dan sedang menunju visi tersebut. Pernyataan tersebut tentunya didasarkan atas membaiknya pendidikan di Provinsi Kaltim yang ditunjukan dengan meningkatnya $\mathrm{AMH}$, meningkatnya rata-rata lama sekolah dan meningkatnya kualitas pendidikan yang ditunjukan dengan program wajib belajar 9 tahun.

AMH meningkatnya sebesar $1.39 \%$ dan rata-rata lama sekolah meningkat 0.05 tahun dibandingkan tahun 2006. Hal tersebut tentunya tidak terlepas dari kebijakan dan komitmen dalam bidang pendidikan. Kebijakan yang dituangkan dalam program antara lain wajib belajar 9 tahun dan 12 tahun, Gerakan Nasional Orang Tua Asuh (GNOTA) terutama penduduk kelompok usia sekolah (umur 7-24 tahun). Sedangkan komitmennya antara lain ditunjukan dari alokasi anggaran pendidikan sebesar 12,09\% dari APBD. Pembangunan sekolah dan kelas baru. Sebagai contoh data tahun 2006 - 2009 menunjukan Sekolah taman kanak-kanak (TK) meningkat sebanyak 100\% dari 653 unit menjadi 1.306 unit, sekolah dasar (SD) negeri meningkat 23 unit dan swasta 37 unit, sekolah menengah pertama (SMP) negeri meningkat 131 unit, sekolah menengah umum (SMU) negeri sebanyak 22 unit dan swasta menurun 47 unit, sekolah menengah kejuruan (SMK) meningkat 486 unit.

Selanjutnya, pencapaian pembangunan dalam bidang pendidikan tahun 2009 sebagai berikut:

1. Angka Buta Huruf (ABH) menurun sebesar $0.58 \%$ pada tahun 2009 dari sebelumnya. Nilai Angka melek huruf (AMH) Provinsi Kaltim pada tahun 2009 sebesar 96.89 persen. Nilai AMH tersebut telah diatas nila i A M n a s i n a 1 . Kabupaten/kota yang memiliki $\mathrm{AMH}$ tertinggi pada tahun yang sama yakni BP dan Btg dengan nilai sebesar 98.35 persen. Sedangkan, kabupaten/kota dengan nilai terendah adalah TT dengan nilai 88.01 persen. Apabila dibandingkan antara AMH provinsi dan kabupaten/kota, maka nilai $\mathrm{AMH}$ yang berada di atas nilai $\mathrm{AMH}$ provinsi meliputi BP, Smd, Trn dan Btg. Kemudian, nilai AMH dibawah provinsi meliputi seluruh kabupaten di Provinsi Kaltim. Capaian tersebut tentunya tidak terlepas dari kondisi geografis antara kabupaten dan kota, wilayah kabupaten memiliki luas lebih dari 98 persen dan kota kurang dari 2 persen dari luas wilayah Provinsi Kaltim. 
Kondisi tersebut tentunya akan memberikan pengaruh terhadap pelayanan dalam bidang pendidikan.

Namun demikian, Prestasi tidak selalu hanya dihitung dari hasil capaian akhirnya, Prestasi perkembangan juga dapat dilihat dari tingkat pertumbuhannya dalam satu waktu tertentu. Bila dilihat perkembangan AMH dari tahun 2007 sampai 2009 kabupaten/kota maka memiliki nilai variasi antara 0.01 - 1.93 persen, sedangkan pertumbuhan AMH Provinsi sebesar 1.19 persen. Selanjutnya, bila dinilai variasi tersebut di skala dengan : $<0.65$ (rendah), $0.65-1.13$ (sedang), dan $>1.13$ (tinggi), maka Blg dan $\mathrm{Br}$ memiliki nilai perkembangan tinggi, Smd dengan nilai sedang dan kabupaten/kota lainnya memiliki nilai pertumbuhan rendah.

2. Rata-rata lama sekolah Provinsi Kaltim meningkat sebesar 0.19 tahun. Tahun 2007 lama sekolah rata-rata 8.66 tahun dan pada tahun 2009 menjadi 8.85 tahun. Peningkatan rata-rata lama sekolah paling tinggi adalah Pr dengan nilai 0,42 tahun dan terendah Smd dengan nilai 0.05 tahun. Selanjutnya jika dibandingkan dengan nilai provinsi, maka $\mathrm{Pr}, \mathrm{Br}$, Blg dan BP memiliki peningkatan diatas provinsi.

3. Angka partisipasi sekolah (APS) meningkat pada tahun 2009 dibandingkan tahun 2007. APS berdasarkan usia sebagai berikut :

- Usia 7 -12 meningkat $0.42 \%$ dari $98 \%$ menjadi $98,42 \%$.

- Usia 13-15 meningkat $1.50 \%$ dari $90.5 \%$ menjadi $91,55 \%$.

- Usia 16-18 meningkat $0.17 \%$ dari $63.90 \%$ menjadi $64.07 \%$.

Sehingga, menurunnya jumlah $\mathrm{ABH}$ dan meningkatnya rata-rata lama sekolah serta APS di Provinsi Kaltim menunjukan keberhasilan dalam bidang pendidikan. Dengan capaian tersebut menunjukan bahwa semakin banyak masyarakat Kaltim yang dapat menikmati pendidikan dengan lebih baik.

\section{Pembangunan bidang Kesehatan}

Sebagaimana telah dijelaskan diatas, rata-rata Angka Harapan Hidup (AHH) seseorang di Provinsi Kaltim tahun 2009 meningkat selama 0.40 tahun dibandingkan tahun 2007. Secara teknis, capaian tersebut sangat dipengaruhi keberhasilan pembangunan bidang kesehatan. Keberhasilan pembangunan bidang kesehatan, maka secara langsung atau tidak langsung akan meningkatkan kualitas hidup masyarakatnya. Oleh karena itu, Provinsi Kaltim telah meningkatkan sarana dan prasarana serta sumber daya manusia bidang kesehatan setiap tahunnya. Data perkembangan bidang kesehatan dalam Kalimantan Timur Dalam Angka 2010 disajikan sebagai berikut :

Tahun 2005 pemerintah telah membangun 190 unit puskesmas dan 642 unit puskesmas pembantu. Sampai dengan tahun 2009 bertambah menjadi 217 unit 
puskesmas atau meningkat $14.21 \%$ dan 666 unit puskesmas pembantu atau meningkat $3.74 \%$. Peningkatan jumlah puskesmas/ puskesmas pembantu tersebut perlu diimbangi dengan jumlah dokter yang memadai. Jumlah dokter Puskesmas pada tahun 2005 sebanyak 466 orang dan pada tahun 2009 menjadi 516 orang atau meningkat $10.73 \%$. Jumlah rumah sakit pada tahun 2007 sebanyak 44 unit dengan jumlah tempat tidur 3.714 dan sampai dengan tahun 2009 jumlah rumah sakit bertambah 4 unit atau meningkat $9.09 \%$ dengan kapasitas tempat tidur bertambah menjadi 4.383 atau meningkat $18.01 \%$. Tenaga medis, paramedis, dan non medis yang bekerja jumlahnya juga mengalami peningkatan. ${ }^{9}$

DMU dengan $\mathrm{AHH}$ tertinggi pada tahun 2009 yakni $\operatorname{Pr}$ (72.74 tahun) dan nilai terendah di Mln (68.22 tahun). Bila ditinjau dari perkembangan $\mathrm{AHH}$ kabupaten/kota dari tahun 2007 sampai 2009, Pr memiliki nilai tertinggi (0.68) dan KK memiliki nilai terendah (0.17). Selanjuntya, DMU dengan AHH yang diatas rata-rata meliputi $\mathrm{Pr}, \mathrm{Br}, \mathrm{Nn}, \mathrm{BP}$ dan Smd. Sedangkan, DMU lainnya memiliki nilai dibawah rata-rata provinsi. Sehingga dengan demikian, pembangunan bidang kesehatan dalam terbaik dan perkembangan tertinggi adalah Pr. Perkembangan AHH Pr tersebut melebihi dari Blg, dimana pada tahun $2007 \mathrm{Blg}$ memiliki nilai tertinggi (72.52) dibandingkan dengan $\operatorname{Pr}(72.06)$.

$\overline{9}$ Kalimantan Timur Dalam Angka 2010.

\section{Pembangunan bidang Ekonomi}

Pertumbuhan suatu wilayah salah satunya diukur dari pertumbuhan ekonominya. Provinsi Kaltim mengalami pertumbuhan yang bervariasi dari tahun ke tahun. Pada tahun 2009, pertumbuhan ekononi dengan migas sebesar $2.32 \%$ atau turun $2.50 \%$ dari $4.82 \%$ pada tahun 2008. Tetapi, pertumbuhan ekonomi tanpa migas meningkat $0.23 \%$ dari $6,36 \%$ menjadi $6,13 \%$. Dengan demikian pada periode tahun 2009, pertumbuhan ekonomi Kaltim lebih besar dipengaruhi oleh aktivitas ekonomi non migas seperti konsumsi rumah tangga, konsumsi pemerintah dan lain-lainnya. Konsumsi rumah tangga berdasarkan harga berlaku $\mathrm{Rp}$. 35.220,6 milyar tahun 2008 menjadi $38.001,5$ milyar.

Seiring dengan pertumbuhan ekonomi, pendapatan perkapita juga mengalami peningkatan. Pada tahun 2009 pendapatan perkapita provinsi tanpa migas meningkat sebesar $\mathrm{Rp}$. 2.562.552,-. Dimana, tahun 2008 pendapatan perkapita tanpa migas sebesar Rp. 15.314.394,- dan pada tahun 2009 sebesar Rp. 17.876.946,-. Kemudian jika dilihat dengan rasio perbandingan kabupaten/kota dengan provinsi, maka KT adalah yang tertinggi (280.85) dan Blg adalah yang terendah (41.89). Dan, kabupaten yang berada diatas nilai provinsi meliputi $\mathrm{Pr}$ (112.36), KT dan Btg (106.59).

Meningkatnya pendapatan perkapita tanpa migas minimal dipengaruhi dua faktor penting sebagai berikut : 
- Pendapatan dan Konsumsi Masyarakat

UMP tahun 2009 meningkat sebesar

Rp. 140.500,- atau meningkat

$17.24 \%$ dibandingkan dengan tahun sebelumnya yang hanya sebesar Rp. $815.000,-$. Rata-rata U pah / g aj i / p e nd a pat a n buruh/karyawan/pegawai perbulan pada tahun 2009 sebesar Rp. 2.130.317,- atau meningkat sebesar $0.54 \%$ dari tahun sebelumnya. Selanjutnya untuk rata-rata kebutuhan layak perbulan pada tahun tahun 2009 sebesar Rp. 1.574.906,- atau meningkat $13.37 \%$ - dari tahun sebelumnya. Jika dibandingkan data pendapatan dan konsumsi kedua tahun tersebut, maka masih terdapat nilai tabungan (saving) sebesar Rp. 555.411,/bulan atau menurun sebesar $26.39 \%$ dibandingkan tahun sebelumnya.

- Menurunnya Angka Pengangguran Angkatan kerja tahun 2009 sebanyak 1.460 .996 orang atau mengalami peningkatan $3,11 \%$ dari tahun 2008. Sebagaian besar tenaga kerja diserap pada sektor pertambangan dan industri yakni sebesar 73,91\%. Sedangkan lainnya bekerja di sektor pertanian, listrik, air, konstruksi, perdagangan, komunikasi, keuangan, dan jasa. Selanjuntya, Pengangguran tahun 2009 turun $0.28 \%$ dibandingkan dengan tahun sebelumnya. Penganguran tahun 2008 sebanyak $11,11 \%$ dan tahun 2009 menjadi $10.83 \%$. Penurunan prosentase pengangguran tentunya akan memberikan dampak yang sangat positif terhadap pendapatan perkapita di Provinsi Kaltim.
Angka kemiskinan secara regional mengalami penurunan. Pada tahun 2008 sebanyak 8,35\% menjadi $7,86 \%$ pada tahun 2009. Potret kemiskinan dari pendidikan maka Tidak/Belum Tamat SD (37,43\%), SD $(30.39 \%)$, SMP (14.08), SLTA $(17.19 \%)$ diatas SLTA $(0.91)$. Potret dari sisi lapangan pekerjaan adalah Tidak Bekerja (5.44\%), pertanian (62.29\%), Industri (5.44\%) dan lainnya $(26.84 \%)$. Dari data tersebut terlihat bahwa penduduk miskin sebagian besar memiliki pendidikan kurang dari 6 tahun dan dalam bidang pertanian.

\section{Analisis IPM Kabupaten/Kota}

Hasil nilai IPM Provinsi Kaltim menunjukan hasil yang exelent. Selanjutnya untuk menjawab bagaimana kualitas pembangunan manusia, maka yang diukur yakni penyebaran pembangunan IPM pada kabupaten/kota. Evaluasi berikutnya y a it u pembangunan IPM kabupaten/kota. Analisa ini menggunakan data pada tahun 2009 seperti pada Tabel 2 .

Alat bantu analisis yang digunakan adalah DEA-Solver LV3.0/ CCR (CCR-O). Model ini digunakan untuk mengetahuai output (hasil) yang paling efisien dengan inputnya. Hasil analisis menunjukan bahwa rata-rata nilai efisiensi sebesar 0.999 atau jika dibulatkan 1.00 (satu) dengan standar deviasi 0.001 . Artinya bahwa pembangunan IPM di setiap KAbupaten/kota telah sangat efisien (optimal). Pembangunan variabel IPM kabupaten/kota telah optimal. Hasil Analisa seperti pada Grafik 2. 


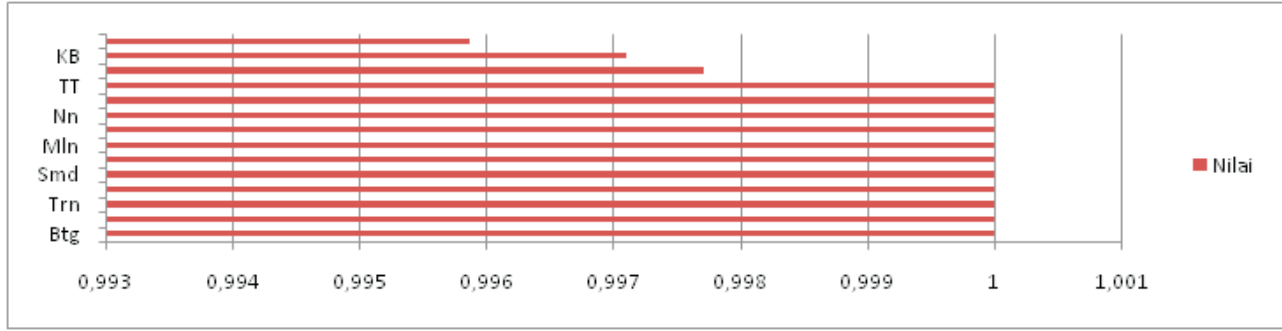

Sumber : Hasil DEA model $=$ DEA-Solver LV3.0/ CCR(CCR-O)

Grafik 2 : Nilai dan Peringkat Efisiensi IPM Kabupaten/Kota di Provinsi Kaltim

Seirama dengan hasil analisis provinsi, hasil analisis IPM Kabupaten/kota juga sangat efisien. Hasil ini menunjukan bahwa pembangunan manusia menyebar secara merata di seluruh wilayah Provinsi Kaltim. Hal tersebut tentunya sangat menarik untuk melihat perkembangan pembangunan pendidikan, kesehatan dan ekonomi kabupaten/kota. Pembahsan selanjuntya melihat gambaran kebijakan dan capaian beberapa kabupaten dan kota dalam pembangunan manusia.

\section{Kota Samarinda (Smd)}

Dalam bidang pendidikan, Pemerintah Kota Samarinda mengalokasikan anggaran pendidikan sebesar Rp. 405.739.719.017. ${ }^{10}$ Program pembangunan pendidikan antara lain wajar 12 tahun, peningkatan mutu pendidikan dan tenaga kependidikan, manajemen pelayanan pendidikan, pendidikan anak usia dini, peningkatan sarana dan prasarana penunjang pendidikan. Untuk melihat pertumbuhan dan perkembangan pembangunan pendidikan dapat dibandingkan dengan tahun 2005. Selama periode 2005 - 2009, Setiap jenjang pendidikan jumlah sekolah meningkat $3.9-100 \%$, jumlah kelas meningkat $4.5-100 \%$, jumlah siswa $6.9-100 \%$ dan jumlah guru $15.1-$ $100 \%$. Jenjang SLTA merupakan tingkatan paling tinggi dibandingkan dengan lainnya, jumlah sekolah bertambah $94 \%$, jumlah kelas meningkat $33.6 \%$ dan guru bertambah $26.7 \%$. Sedangkan untuk jumlah siswa, jenjang TK bertambah paling banyak yakni 27.3\% atau 2.164 siswa. Dilihat dari statusnya, jumlah sekolah swasta bertambah lebih banyak dibandingkan dengan sekolah negeri, terutama untuk jenjang TK dan SD. Hal ini menunjukan peningkatan partisipasi masyarakat dalam bidang pendidikan.

Program pembangunan bidang kesehatan kota Smd antara lain standarisasi pelayanan kesehatan, pencegah dan penanggulangan penyakit, pengadaan, peningkatan dan perbaikan sarana dan prasarana puskesmas / puskesmas pembantu dan jaringannya, peningkatan pelayanan kesehatan lansia, perbaikan gizi masyarakat. Dilihat dari jumlah fasilitas kesehatan, Balai pengobatan (sertifikat) berkurang 11 unit, Puskesmas bertambah 1 unit, puskemas

${ }^{10}$ 2009, Alokasi Anggaran Pendidikan Turun Rp47 M http://www.bappeda.samarinda.go.id/berita.php?id=142 
keliling bertambah 23 unit, pembantu puskesmas berkurang 2 unit, rumah sakit umum bertambah 2 unit, Rumah sakit bersalin/jiwa/bedah tetap, Apotek berkurang 31 unit. Berdasarkan status, tahun 2009 Rumah sakit Swasta memilki tempat tidur lebih banyak 97 unit dan pengunjung pasien juga lebih banyak 135,901 orang. Selanjuntya, rata-rata pengobatan melalui puskesmas sebanyak 350,449 orang atau meningkat 8.477 orang dibandingkat tahun 2005.

Dalam bidang ekonomi, Pemerintah Kota Samarinda menggunakan Strategi jalur ganda (dual track strategy). " Strategi ini bertujuan mencapai pertumbuhan ekonomi secara berkualitas (pembangunan yang merata). Pencapaian dalam bidang ekonomi ditunjukan dengan peningkatan PDRB tanpa migas sebesar Rp. 2.789.270 dibandingkan dengan tahun 2007. Namun demikian, jika dibandingkan dengan PDRB tanpa migas provinsi mengalami penurunan sebesar $14.43 \%$. Kondisi tersebut menunjukan bahwa sebagian kabupaten/kota memiliki pertumbuhan yang lebih baik dibandingkan dengan Kota Smd.

\section{Kota Balikpapan (BP)}

Visi Pemerintah Kota Balikpapan adalah "Terwujudnya Kualitas Pendidikan Yang Berwawasan Imtaq Dan Iptek, Mandiri, Dinamis, Dan Beretos Kerja Tinggi, Berdaya Saing Global Yang
Didukung Pelayanan Prima".12 Pencapaian visi dilakukan antara lain dengan menyelenggarakan peningkatan kualitas penyelenggaraan pendidikan, memberikan kemudahan dan fasilitasi pengembangan potensi masyarakat (learning society), meningkatkan kualitas proses pendidikan dan meningkatkan partisipasi masyarakat. Untuk mendukung tercapainya visi dan misi tersebut, Pemerintah Kota Balikpapan mengalokasikan 30 persen anggaran daerah untuk peningkatan mutu pendidikan. Prosentase tersebut diatas standar minimal yang diamanatkan undang-undang (UU). Anggaran Pendapatan Belanja Daerah (APBD) Kota Balikpapan telah ditetapkan sebesar Rp 1,4 triliun. $^{13}$ Salah satu program unggulan dalam meningkatkan pemerataan dan kualitas pendidikan adalah program wajib belajar pun disesuaikan dari 9 tahun menjadi 12 tahun. Selanjutnya dalam penyediaan sarana pendidikan di Kota samarinda mengalami peningkatan dari tahun ke tahun. Kondisi tersebut dapat dilihat dari penambahan jumlah murid yang diiringi dengan penambahan jumlah sekolah, jumlah guru dan jumlah kelas. Penyediaan sarana paling besar pada jenjang TK (36.2\%) dan SMP $(5.8 \%)$, sedangkan lainnya berkurang. Bila dilihat dari statusnya maka partisipasi masyarakat mendominasi pada jenjang TK, SD, dan SLTP, sedangkan pemerintah daerah di jenjang SLTA. Namun demikian, lambatnya perkembangan

\footnotetext{
${ }^{11}$ Bab iv strategi pembangunan daerah, rpjmd kota samarinda 2005-2010 diakses dari

http://www.bappeda.samarinda.go.id/data/files/rpjm_04.pdf

${ }^{12}$ visi \& misi di akses http://disdik.balikpapan.go.id/webdisdik/index.php/tentang-kami/visi-a-misi

${ }^{13}$ anggaran pendidikan balikpapan rp 420 miliar http://www.tempo.co/hg/pendidikan/2010/01/01/brk,20100101216713,id.html
} 
sarana tidak mengurangi semangat meningkatkan kualitas dan pemerataan pendidikan. Kondisi tersebut ditunjukan dengan jumlah siswa meningkat $18.6 \%$ untuk TK, SD dan SLTP sebanyak $12 \%$, dan SLTA sebanyak $9.1 \%$. sedangkan peningkatan kualitas pendidikan antara lain dengan penambahan jumlah guru antara $13-54.4 \%$.

Dalam bidang kesehatan, Kota Balikpapan bertekad menjadi lembaga pembiayaan kesehatan, fasilitator, regulator dan pemberi pelayanan kesehatan yang efektif dan mempunyai standar internasional". ${ }^{14}$ Untuk mencapai hal tersebut dengan delapan misi meliputi : menjamin pelayanan untuk seluruh penduduk, meningkatkan kompetensi SDM kesehatan, mengelola dan menyelengarakan pembiayaan kesehatan antara pemerintah,swasta dan masyarakat, pengawasan dan perijinan tenaga dan sarana, pengendalian mutu pelayanan, surveilands dan sistem informasi kesehatan, mengembangkan perilaku sehat dan penelitian dan pengembangan. Data tahun 2009 menunjukan bahwa fasilitas kesehatan yang berhasil dibangun sampai dengan tahun 2009 sebanyak 122 unit meliputi 9 Rumah Sakit (Negeri dan Swasta), 18 Balai Pengobatan dan Klinik, 3 Klinik Bersalin, 10 Lab Klinik, 4 Fasilitas Fisioterapi, 27 Puskesmas yang didukung oleh 11, Puskesmas
Pembantu dan 26 unit, Puskesmas Keliling 11 Sarana Rontgen dan 3 Rumah Sakit Bersalin. ${ }^{15}$ Selanjuntya, dalam bidang anggaran kesehatan tahun 2007 Rp 20 miliar dan tahun 2006 Rp 11 miliar untuk Jaminan Kesehatan Daerah (Jamkesda) yang merupakan "Pemerintah Kota berkomitmen menjamin karena kesehatan menjadi kebutuhan masyarakat," ${ }^{16}$ Peserta Jamkesda berjumlah 269.768 jiwa dari total 621.608 penduduk Balikpapan. Sisanya dijamin oleh Jamkesmas, asuransi kesehatan swasta, dan jaminan kesehatan dari perusahaan.

Dalam bidang ekonomi, PDRB Perkapita tanpa migas Kota balik papan sebesar $71.82 \%$ dari PDRB per kapita tanpa migas provinsi atau Rp. $12.832 .758,-$. S edangkan pengeluarannya sebesar Rp. 646.650/bulan atau masih memiliki saving sebesar Rp. 5.072.958,-/tahun. Keberhasilan pembangunan ekonomi juga ditunjukan dari program pengentasan kemiskinan. "Tahun 2007 lalu ada sekitar 27 ribu orang miskin, kemudian pada 2009 lalu kita data ulang ada sekitar 24 ribu orang miskin". ${ }^{17}$ Namun disisi lain, angka kemiskinan di kota Balikpapan juga dipengaruhi oleh banyaknya pendatang miskin.

\section{Kota Bontang (Btg)}

"Bontang Cerdas Rujukan Sistim Pendidikan Nasional"

\footnotetext{
visi dinas kesehatan kota balikpapan,

http://dkk.balikpapan.go.id/index.php?option=com content\&task=view\&id=26\&itemid=49

Balikpapan dalam angka 2010 bagian 5 : sosial

${ }^{6}$ jaminan kesehatan daerah: saling tolong untuk yang sakit diakeses http://www.dk-insufa.info/kesehatan/400jaminan-kesehatan-daerah-saling-tolong-untuk-yang-sakit?lang=

${ }^{17}$ lima tahun, 7 ribu warga miskin dientaskan pendatang baru sumbang angka warga miskin sebanyak 3 ribu orang diakses http://www.korankaltim.co.id/read/news/2011/5651/
} 
merupakan visi Kota Bontang dalam bidang pendidikan. Untuk mencapainya diselenggarakan misi antara lain perluasan dan pemerataan pendidikan yang bermutu bagi seluruh masyarakat, membantu dan memfasilitasi pengembangan potensi anak, meningkatkan keprofesionalan dan akuntabilitas lembaga pendidikan, memberdayakan peran serta masyarakat serta manajemen pendidikan modern yang berbasis Informasi Teknologi. Misi tersebut dituangkan dalam 14 program pilat utama yaitu :

1) Wajib belajar Dikdasmen 12 Tahun, 2) Jumlah Anak usia sekolah yang tidak bersekolah, 3) alternatif layanan pendidikan, 4) Tiga sasaran pendidikan, 5) Jumlah tiga buta, 6) Akreditasi lembaga pendidikan formal dan nonformal, 7) Daya serap lulusan, 8) Akses layanan pendidikan yang berbasis IT. 9) Standar nasional sekolah, 10) Standar ISO 9001:2000 untuk SMK, 11) Standar internasional untuk SMA, 12) Kecukupan dan kecakapan guru, dan 13) Sarana Prasarana Pendidikan, serta 14) Kompetensi siswa. ${ }^{18}$

Anggaran pendidikan minimal 20 persen dalam APBD, tertuang dalam Rencana Strategis Bidang Pendidikan Kota Bontang 2005-2010. ${ }^{19}$ Hasil pembangunan dalam bidang pendidikan antara lain ditunjukan dengan tingginya AMH sebesar 99,15\% atau nilai tertinggi di Provinsi Kaltim. Bahkan, keberhasilan tersebut telah diakui secara nasional, sehingga Kota Btg termasuk dalam 42 yang tidak mendapatkan Dana Alokasi Khusus (DAK) Pendidikan. Suyanto mengungkapkan, penghentian pemberian DAK pendidikan ke-42 kabupaten/kota ini disebabkan daerahdaerah tersebut dinilai sudah mampu secara finansial untuk mendanai anggaran pendidikan. Dari pendataan sekolah rusak di 2 kabupaten/kota itu juga menyebut tidak ada sekolah dalam kategori rusak berat yang perlu direhabilitasi. ${ }^{20}$ Selanjutnya, Pembangunan sarana sekolah paling banyak pada tahun 2009 berada di jenjang pendidikan SLTP dan SLTA peningkatannya mencapai $17.6 \%$ dan sebagian besar merupakan partisipasi masyarakat (swasta). Sedangkan, pemerataan pendidikan juga terlihat pada peningkatan jumlah siswa pada setiap jenjang pendidikan.

Kemudian, dalam bidang kesehatan ditetapkan visi "Terwujudnya Masyarakat Bontang Yang Sehat". ${ }^{21}$ Untuk mewujudkan Visi Dinas Kesehatan Kota Bontang maka ditetapkan misi yaitu sebagai berikut:

- $M$ e $n$ g g e r a k k a n d a n memberdayakan masyarakat untuk hidup sehat.

- Meningkatkan akses masyarakat

\footnotetext{
${ }^{8}$ empat belas indikator bontang cerdas http://www.kaltimpost.co.id/?mib=berita.detail\&id=79334 ${ }^{19}$ empat belas indikator bontang cerdas

http://www.kaltimpost.co.id/index.php/main/praca/account_manger_lokalizacja_poznan?mib=berita.detail\&id= 79334

${ }^{20} 42$ daerah tak dapat dak pendidikan : http://djkd.depdagri.go.id/?jenis=news\&p=detail_berita\&id=142\&kd=b

${ }^{21}$ visi \& misi dinas kesehatan kota bontang, http://dinkes.bontangkota.go.id/index.php/selayang-pandang/visi-amisi
} 
terhadap pelayanan kesehatan yang berkualitas.

- Meningkatkan sistem surveilans, monitoring dan informasi kesehatan.

- Meningkatkan sistem pembiayaan kesehatan.

Keberhasilan pembangunan bidang kesehatan, salah satunya ditunjukan dengan meningkatnya $\mathrm{AHH}$ masyarakat kota Btg dari 71.89 tahun menjadi 72.26 tahun. Dimana, AHH akan sangat erat hubungannya dengan pelayanan kesehatannya. Peningkatan pelayanan keseatan antara lain dengan bertambahnya fasilitas kesehatan seperti 1 unit Rumah sakit, 6 unit Puskesmas Pembantu, 5 unit Balai Pengobatan dan 5 unit apotik, dibandingkan dengan tahun 2008.

Prestasi kota bontang dalam bidang ekonomi yakni meningkatnya kemampuan daya beli masyarakat. PDRB per kapita tanpa migas menempatkan peringkat kedua setelah Kabupaten Kutai Timur dengan nilai Rp. 19.045.443 atau 106,59 dari PDRB Provinsi. Dilihat dari sisi pengeluaran perkapita maka hanya sebesar Rp. 7.552.920, sehingga masih terdapat saving sebesar Rp. 11.492.523,-. Dari sisi kemiskinan, berkurang sebesar $0.5 \%$ dibandingkan dengan tahun 2008. Kondisi tersebut memberikan gambaran bahwa kemampuan daya beli / ekonomi rakyat telah baik. Sedangkan, dilihat dari tenaga kerja, maka hanya sebesar $5.67 \%$ yang mencari pekerjaan dan lainnya telah bekerja dalam berbagai sektor seperti pertanian, perkebunan, perburuan, kehutanan dan perikanan ; pertambangan dan penggalian; industri pengolahan; listrik, gas, dan air; konstruksi; perdagangan, rumah makan dan jasa akomodasi; angkutan, pergudangan, dan komunikasi; dan lainnya. Dan sebagian besar penduduk bekerja pada sektor perdagangan, rumah makan dan jasa akomodasi (23.84\%) serta jasa kemasyarakatan, sosial, dan budaya $(24.87 \%)$.

\section{Kab.Paser}

Anggaran pendidikan Kabupaten Paser tahun 2009 lebih dari $20 \%$ APBD atau sebesar 279 miliar. $^{22}$ Anggaran tersebut untuk menyelengarakan program-program dalam bidang pendidikan antara lain $:^{23}$ Wajib Belajar (Wajar) 9 Tahun, Peningkatan Manajemen Pelayanan Pendidikan, Peningkatan Mutu Pendidikan dan Tenaga Kependidikan, Peningkatan Sarana dan Prasarana, Peningkatan Pelayanan Pendidikan, Peningkatan Mutu Pendidikan dan Tenaga Kependidikan, Pemberantasan Buta Huruf, dan lainnya.

Pada tahun 2009, jumlah fasilitas dan tenaga pendidikan seperti sekolah TK mencapai 96 unit dan guru 369 orang dengan 3.581 siswa. Sekolah SD mencapai 225 unit, 1353 ruang kelas dan rombongan belajar serta guru 1.987 orang dengan 31.143 siswa. Sekolah SLTP mencapai 68 unit dan jumlah guru sebanyak 925 orang dengan 11.819 siswa. Sekolah SLTA sebanyak 32 unit dan 698 guru .serta

\footnotetext{
${ }^{22}$ tahun ini pemkab alokasikan dana pendidikan rp 208 miliar http://www.paserkab.go.id/publikasi/89

${ }^{23}$ rencana program dan kegiatan indikatif http://pendidikan.paserkab.go.id/cetak2.php?id=116
} 
7.897 siswa. Pencapaian lainnya dalam bidang pendidikan adalah 96,38 \% penduduknya telah bebas dari buta huruf. Kondisi tersebut meningkat 1.29 $\%$ dari tahun 2008 .

Dalam bidang Kesehatan, Kabupaten Paser menetapkan 22 program prioritas antara lain : Perbaikan Gizi Masyarakat, Pelayanan usia lanjut, Pembinaan puskesmas, Kesehatan Anak, Kesehatan Ibu dan $\mathrm{KB}$, Farmasi dan peralatan medis, Rumah Sakit, Peran serta masyarakat, Pencegahan penyakit dan Imunisasi, dan lainnya. Penyelenggarakan program tersebut antara lain dibuktikan dengan fasilitas kesehatan tahun 2009, rumah sakit lunit, puskesmas 17 unit, puskesmas pembantu 97 unit, puskesmas keliling 27 unit dan klinik swasta 17 unit. Bila dibandingkan dengan tahun 2005, maka penambahan puskesmas keliling merupakan yang paling banyak yakni 10 unit. Disisi lain partisipasi swasta/masyarakat juga meningkat dengan membuka klinik sebanyak 17 unit. Selain fasilitas sarana, Tenaga kesehatan juga menjadi factor penting, tahun 2009 tercatat Dokter umum 19 orang, dokter gigi 8 orang, sarjana kehatan masyarakat 19 orang, bidan 62 orang, perawat 93 orang dan masih banyak lainnya.

Pencapaian dalam bidang kesehatan antara lain dapat diukur dengan Angka Harapan Hidup. Tahun 2009 angka harapan hidup masyarakat Kabupaten Paser sebesar 72.74 tahun atau meningkat 0.68 tahun dibandingkan tahun 2006. Angka tersebut merupakan nilai tertinggi di
Provinsi Kaltim.

Dalam bidang Ekonomi, Kabupaten Paser menargetkan pencapaian pertumbuhan ekonomi sebesar $9.89 \%$ pada tahun 2009. Sedangkan, pertumbuhan ekonomi provinsi pada tahun yang sama sebesar 2.09\%. Mestipun lebih rendah dari targetnya, pertumbuhan ekonomi rakyat meningkat dari tahun ketahuan. Secara nominal PDRB perkapita tanpa migas kabupaten Paser meningkat sebesar Rp. 7.968.826,- dibandingkan dengan tahun 2007. Apabila dibandingkan dengan PDRB perkapita tanpa migas provinsi maka lebih besar yakni $112.36 \%$. Selanjuntya pengeluaran perkapita pada tahun 2009 sebesar Rp. 626.470,-. Angka tersebut masih lebih rendah dari nilai pengeluaran perkapita provinsi yang sebesar Rp. 638.730,-. Kondisi tersebut menguntungkan masyarakat Kabupaten Paser dimana memilki pendapatan yang lebih tinggi dan pengeluaran lebih rendah dibandingkan dengan provinsi. Nilai pendapatan yang dapat di saving ratarata sebesar Rp. 12.558.748,Selanjuntya, dilihat dari sisi prosentase penduduk miskin, Kabupaten Paser memiliki $9.14 \%$ atau 18.400 orang penduduk miskin. Konisi tersebut menggambarkan bahwa pembangunan ekonomi relative merata.

\section{Kab. Kutai Barat (KB)}

Visi Kabupaten Kutai Barat "Kutai Barat Yang Masyarakatnya Semakin Cerdas, Sehat, Produktif dan Sejahtera Berbasiskan Ekonomi Kerakyatan" ${ }^{24}$ Delapan misi yang

\footnotetext{
${ }^{24}$ visi Dan Misi http://www.kubarkab.go.id/profil.php?id=4
} 
dilaksanakan untuk mencapai visi antara lain pembangunan infrastruktur, meningkatkan kualias SDM, mensejahterakan masyarakat local, meningkatkan pertumbuhan ekonomi dan lain sebagainya. Selanjuntya beberapa program yang diselenggarakan antara lain meliputi : ${ }^{25}$ percepatan pelaksanaan wajib belajar sembilan tahun; peningkatan pelayanan pendidikan, kesehatan; pengembangan pendidikan dasar, menengah dan tinggi; peningkatan akses masyarakat terhadap pendidikan dan kesehatan yang lebih berkualitas.

Salah satu sudut keberhasilan pembangunan pendidikan adalah bertambahanya fasilitas pendidikan antara lain jumlah sekolah, jumlah murid dan jumlah guru. Kalimantan Barat dalam angka 2009 menunjukan bahwa jumlah sekolah dari tingkat SD sebanyak 232 unit, 68 unit SLTP dan 33 untuk tingkat SMU/SMK. Sedangkan untuk jumlah murid SD sebanyak 23.315 siswa, SLTP sebanyak 8.146 siswa dan untuk SMU/SMK sebanyak 3.364 siswa. Kemudian, jumlah guru SD sebanyak 2.198 orang, SLTP sebanyak 574 orang dan SMU/SMK sebanyak 418 guru. Keberhasilan dalam bidang pendidikan antara lain dapat dilihat dari meningkatnya AMH sebesar $0.48 \%$ dan rata-rata lama sekolah selama 0.11 tahun dibandingkan tahun 2007.

Pembangunan bidang kesehatan antara lain dilakukan dengan peningkatan akses masyarakat mendapatkan kesehatan berkualitas. Untuk itu, Kutai Barat sampai tahun
2009 telah memiliki Rumah Sakit sebanyak 1 unit, Puskesmas sebanyak 23 unit, Puskesmas Pembantu sebanyak 88 unit, Balai pengobatan sebanyak 13 unit, Dokter Praktek sebanyak 36 unit. Klinik KB sebanyak sebanyak 141 unit, Posyandu sebanyak 274, Apotik sebanyak 11 unit, dan Toko Obat sebanyak 10 unit, Sedangkan, Tenaga kesehatan sebanyak 663 orang yang meliputi dokter umum sebanyak 40 orang, perawat sebanyak 422 orang, bidan sebanyak 102 orang, sarjana kesehatan masyarakat sebanyak 31 orang. Dan lainnya meliputi dokter ahli, dokter gigi, ahli gizi, apoteker dan lainnya. Dengan fasilitas sarana dan prasarana tersebut telah meningkatkan Angka harapan hidup sebesar $0.38 \%$ dibandingkan tahun 2007.

Selanjutnya dalam bidang ekonomi, PDRB per kapita tanpa migas secara nominal meningkat sebesar Rp. 3.555.616,- dibandingkan tahun 2007. Tetapi jika dibandingkan dengan PDRB Provinsi maka turun sebesar $9 \%$. Kondisi tersebut menunjukan bahwa beberapa kabupaten/kota memiliki pertumbuhan lebih tinggi dibandingkan KB. Sedangkan pengeluaran perkapita sebesar Rp. 625.570,- atau meningkat Rp. 4.070,dibandingkan tahun 2007. Dengan demikian secara nominal masyarakat memiliki saving rata-rata $\mathrm{Rp}$. 5.216.924/tahun. Selanjutnya, jika perkembangan pembangunan dilihat dari jumlah penduduk miskin yang masih 14.300 orang, maka penyebaran pertumbuhan belum merata. Sehingga perlu diberdayakan ekonomi mereka menjadi lebih baik. Apabila merujuk

${ }^{25}$ Kebijakan Umum, SDM http://www.kubarkab.go.id/kebijakan.php?id=6 
dengan data provinsi maka mereka itu yakni masyarakat dengan pendidikan di bawah SD dan yang bekerja dalam bidang pertanian.

\section{Kab. Kutai Kartanegara (KK)}

Salah satu wujud keberhasilan pembangunan pendidikan yakni meningkatnya AMH. Pada tahun 2009, AMH di KK sebesar 97.15\% dan ratarata lama sekolah 8.38 tahun. Hasil tersebut tentunya dipengaruhi oleh banyak faktor diantaranya fasilitas dan tenaga pendidik. Fasilitas sekolah tahun 2009 meliputi TK sebanyak 308 unit, SD sebanyak 473 unit, SLTP sebanyak 133 unit, dan SMU/SMK sebanyak 77 unit. Sedangkan, jumlah tenaga pendidik dan siswa antara lain sebagai berikut: TK sebanyak 1.149 guru dengan 11.477 siswa, SD Negeri sebanyak 6.823 guru dengan 78.488 siswa, MI Negeri sebanyak 47 guru dengan 579 siswa, MI Swasta sebanyak 161 guru dengan 1.305 siswa, SMP negeri sebanyak 1.662 guru dengan 22.008 siswa, SMP swasta sebanyak 332 guru dengan 3.763 siswa, MTs Negeri sebayak 114 guru dengan 1.412 siswa, MTs Swasta sebanyak 632 guru dengan 4.375 siswa, SMA Negeri sebanyak 721 guru dengan 9.665 siswa, SMA Swasta sebanyak 180 guru dengan 2.156 siswa. Selanjuntya, rasio guru dengan siswa SD, SMP dan SMA antara 11 - 13 siswa / guru dan rasio untuk MI, MTs dan MA antara 8-12 siswa/guru.

Dalam bidang kesehatan, Kabupaten Kutai Kartanegara bertekad mewujudkan "Masyarakat Kutai Kartanegara Sehat, Mandiri dan

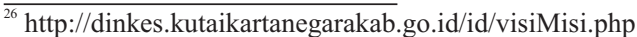

Berkualitas. ${ }^{26}$ Oleh karena itu, Kutai Kartanegara memiliki tiga misi utama meliputi :

- Menggerakkan pembangunan Kabupaten Kutai Kartanegara berwawasan kesehatan.

- Memelihara dan meningkatkan pelayanan kesehatan yang bermutu, merata, dan terjangkau.

- Memelihara dan meningkatkan kesehatan Individu, keluarga, dan masyarakat beserta lingkungan.

Keberhasilan pembangunan kesehatan dapat dilihat dati meningkatnya AHH masyarakat Kukar. Angka tersebut meningkat 0.17 tahun dibandingkan tahun 2007 atau menjadi 67.85 tahun. Peningkatan tersebut tentunya tidak terlepas dari meningaktkanya sarana dan prasarana bidang kesehatan. Sampai dengan tahun 2009, Kukar telah memiliki 2 unit rumah sakit yakni Rumah Sakit Umum Daerah (RSUD) A.M. Parikesit di Kecamatan Tenggarong dan RSUD Aji Batara Agung Dewa Sakti di Kecamatan Samboja., 30 unit puskesmas yang tersebar di seluruh kecamatan, dan 160 unit puskesmas pembantu atau meningkat 20 unit dibandingkan tahun 2008. Selanjutnya, tenaga kesehatan pada lingkungan puskesmas antara lain 89 dokter dan 37 dokter gigi.

PDRB per kapita tanpa migas Kukar tahun 2009 sebesar Rp. $12.723 .764,-$ atau $71.21 \%$ dibandingkan dengan PDRB provinsi. Apabila dilihat dari tahun 2007 - 2009 secara nominal mengalami peningkatan sebesar Rp. 3.555.616,-, 
tetapi jika dibandingkan dalam prosentase provinsi, maka Kukar mengalami penurunan sebesar $8.7 \%$. Artinya pembangunan ekonomi masyarakat di sebagian kabupaten/kota di Kaltim lebih baik. Selanjuntya, pengeluaran rata-rata perkapita sebesar Rp. 625.750,-. Dengan demikian masih terdapat saving sebesar Rp. 7.506.840,/tahun. Tetapi jika di hitung menggunakan rata-rata kebutuhan hidup layak sebesar Rp. 1.505.515,maka masih minus sebesar Rp. 5.342.415,-/tahun. Kemudian dilihat dari prosentase penduduk miskin, Kukar memiliki $6.78 \%$ penduduk miskin atau 42.500 orang. Dengan kondisi tersebut, maka dibutuhkan peningkatan kualitas pemerataan dalam pembangunan ekonomi rakyat.

\section{Kab. Malinau (Mln)}

Capaian dalam bidang pendidikan Kabupaten Malinau antara lain dapat dilihat dari capaian AMH sebesar $93.84 \%$ dan rata-rata lama sekolah selama 7.75 th. Pada tahun 2009 untuk meningkatkan mutu pendidikan, Kabupaten Malinau menyiapakan anggaran pendidikan mencapai 20 persen. ${ }^{27}$. Untuk meningkatkan mutu pendidikan dengan meningkatkan beberapa hal antara lain sekolah, guru, serta sarana dan prasarana lainnya. Sampai tahun 2009, Kabupaten Malimau telah memiliki sarana berupa 87 unit SD, 24 unit SLTP, 14 unit SMU dan 3 unit SMK. Sedangkan jumlah tenaga pendidik sebanyak 850 guru SD, 267 guru SLTP, 189 guru SLTA, dan 49 guru SMK. Kemudian, rincian jumlah murid masing-masing jenjang sebagai berikut 9.761 murid SD, 3.281 murid SLTP, 2.680 murid SMU dan 362 murid SMK. Jika dibandingkan dengan tahun sebelumnya Jumlah guru mengalami peningkatan sebesar 20,12 persen dan jumlah murid mengalami peningkatan sampai dengan 25,30 persen.

Rata-rata angka harapan hidup Kabupaten Malinau adalah selama 68.22 tahun. Kondisi tersebut meningkat 0.21 tahun dibandingkan denagan tahun 2007. Segabai komitmen pembangunan kesehatan meningkatkan sarana dan prasana kesehatan. Pada tahun 2009, sarana kesehatan yang telah dimilikinya meliputi Rumah Sakit sebanyak 1 unit, Puskesmas sebanyak 13 unit, Puskesmas Pembantu 40 unit, dan Posyandu 96 unit. Jumlah tenaga kesehatan sebanyak 366 orang yang terdiri dari dokter umum 21 orang, dokter gigi 5 orang, tenaga medis 110 orang, 198 orang tenaga perawat dan 37 orang bidan.

Dalam bidang ekonomi, PDRB per kapita tanpa migas sebesar Rp.9,357,443,- atau 52,37\% dari PDRB provinsi. PDRB tersebut menurun dari tahun-tahun sebelumnya yang mencapai $57,52 \%$ dan $65.59 \%$. Disisi lain rata-rata pengeluaran per kapita di Kabupaten Malinau lebih tinggi dibandingkan dengan kabupaten lainnya seperti Kabupaten Kukar. Dari sisi kemiskinan, Malinau memiliki 10.300 orang atau $14.57 \%$ penduduk miskin. Hal tersebut menunjukan bahwa pembangunan ekonomi dan

\footnotetext{
Anggaran Pendidikan Capai 20 Persen :

http://www.kaltimpost.co.id/index.php/main/praca/account_manger_lokalizacja_poznan?mib=berita.detail\&id= 49072
} 
akses peningkatan kemampuan daya beli masih belum merata. Masih terdapat $1.07 \%$ angkatan kerja yang belum memiliki pekerjaan. Penduduk miskin paling banyak berasal dari sektor pertanian dengan pendidikan SD kebawah. Sehingga untuk peningkatan PDRB per kapita tanpa mingas perlu membangun sektor tersebut dengan labih baik.

\section{Kab. Bulungan (Blg)}

Sebagaimana telah dijelaskan diatas, IPM Kabupaten Bulungan tahun 2009 sebesar 74,30. Nilai tersebut tentunya tidak terlepas dari pembangunan pendidikan, kesehatan dan ekonomi rakyat. Dalam pendidikan, Kabupaten Bulungan menyediakan anggaran sebesar 23,90 persen atau Rp175 miliar lebih. Anggaran tersebut antara lain digunakan untuk peningkatan sarana pendidikan. Sampai tahun 2009, kabupaten bulungan telah memiliki antara lain SD sebanyak 128 unit, SMP sebanyak 48 unit, SMU sebanyak 14 unit. Jumlah termasuk berlum termasuk MI, MTs dan MA. Dengan sarana tersebut telah meningkatkan akses pendidikan masyarakat hingga $93,56 \%$ penduduk telah terbebas dari buta huruf. Selain itu, rata-rata lama sekolah juga meningkat menjadi 7.88 tahun.

Dalam bidang kesehatan, Angka harapan hidup meningkat sebesar 0.21 tahun atau menjadi 72.73 tahun, dibandingkan dengan tahun 2007 yang sebesar 72.52. Nilai tersebut merupakan cerminan dari hasil pembangunan kesehatan di Kabupaten Bulungan. Penyediaan fasilitas sarana dan tenaga kesehatan merupakan kunci keberhasilan dalam pembangunan kesehatan. Untuk sarana kesehatan, Kabupaten Bulungan telah memiliki antara lain RSUD Dr. H. Soemarno Sosroatmodjo, 12 unit puskesmas, 36 unit Puskesmas pembantu, 10 unit Puskesmas keliling, 157 unit posyandu, 7 unit apotek, dan 8 unit toko obat. Sedangkan tenaga kesehatan yang telah tersedia antara lain 62 orang tenaga medis, 337 orang tenaga perawat dan bidan, 10 orang tenaga farmasi, 15 orang tenaga gizi, 13 orang sanitasi dan 24 orang tenaga kesehatan masyarakat.

Selanjutnya dalam bidang ekonomi, tahun 2009 menunjukan PDRB per kapita tanpa migas sebesar Rp. 7.484.822 atau hanya $41.89 \%$ dari PDRB provinsi. Nilai tersebut secara nominal dan prosentase turun dibandingkan dengan tahun 2008. Sedangkan, rata-rata pengeluaran per kapita sebesar Rp. 633.850,-. Nilai tersebut lebih tinggi dibandingkan dengan sebagian kabupaten lainnya. Penurunan PDRB tersebut tentunya tidak terlepas dari angka kemiskinan sebesar $16.5 \%$ dan pencari kerja sebesar $8.42 \%$. Sebagian besar tenaga kerja berkeja pada sektor pertanian yakni sebesar $60,30 \%$. Dengan melihat kondisi tersebut tentunya perlu perbaikan penyerapan tenaga kerja dan perbaikan ekonomi terutama pekerja dalam bidang pertanian.

\section{F. PENUTUP}

Hasil pembahasan tersebut di atas dapat disimpulkan bahwa pembangunan manusia di Provinsi Kaltim telah Efektif dan Efisien. Efektif karena telah mencapai sasaran dalam peningkatan IPM dari tahun ke tahun, bahkan menempatkan Kaltim dalam peringkat 5 besar. Efisien karena 
sumber daya yang digunakan sesuai dengan hasilnya. Beberapa kebijakan untuk meningkatkan IPMnya antara lain dengan program wajib belajar 12 tahun, alokasi anggaran minimal 20\% untuk pendidikan, peningkatan dan penambahan sarana pendidikan dan kesehatan, program puskesmas keliling, jaminan kesehatan masyarakat dan lainnnya. Selanjutnya, untuk kualitas pembangunan manusia dapat dikatakan baik. Hal ini dapat dilihat dari pencapaian nilai IPM yang "relatif rata-rata". Hal ini menunjukan terjadinya pemerataan pembangunan manusia di seluruh wilayah Provinsi Kaltim.

Namun demikian, ada beberapa hal yang dapat disarankan untuk mengoptimalkan kualitas peningkatan IPM kabupaten/kota di Provinsi Kaltim antara lain meningkatkan angka melek huruf, menambah tenaga pendidik secara proposional / penyebaran tenaga pendidik lebih proposional, peningkatan kemampuan daya beli masyarakat khususnya pekerja pada sector pertanian.

\section{DAFTAR PUSTAKA}

Suripto, 2010, Urgensi Evaluasi Pendidikan Anak Usia Dini Sebagai Upaya Peningkatan Indeks Pembangunan Manusia Di Provinsi Gorontalo, Jurnal Wacana Kinerja, Pusat Kajian Dan Penddikan Dan Pelatihan Aparatur I - Lembaga Administrasi Negara Hal. $276-289$

Suripto, 2011, Best Practice Efisiensi Pembangunan Bidang
Kesehatan Provinsi Kalimantan Timur, Proceeding Simposium Nasional Otonomi Daerah : Best Practices Dalam Penyelenggaraan Otonomi Daerah hal. 228 -234, Fisip Untirta

Ringkasan data Indikator Penting Pembangunan Kaltim Informasi Data Tahun 2010$2011-$ P D R B d a n Pertumbuhan Ekonomi Hal. 35

Rencana Pembangununan Jangka Menengah Daerah Provinsi Kalimantan Timur 2009 2014

Kondisi Sosial Ekonomi dan Indikator Penting Kalimantan Timur Edisi Januari 2011 - Badan Pusat Statistik Provinsi Kalimantan Timur.

Badan Pusat Statistik (BPS) Provinsi Kalimantan Timur, 2010, Kalimantan Timur Dalam Angka 2010, Samarinda, Badan Pusat Statistik (BPS) Provinsi Kalimantan Timur

Badan Pusat Statistik (BPS) Kota Balikpapan, 2010, Balikpapan Dalam Angka 2010 , Balikpapan, Badan Pusat Statistik (BPS) Kota Balikpapan

Badan Pusat Statistik (BPS) Kota Samarinda, 2010, Samarinta Dalam Angka 2010 , Samarinda, Badan Pusat 
Statistik (BPS) Kota Samarinda

Badan Pusat Statistik Kota Bontang, 2010, Bontang Dalam Angka 2010, Bontang, Badan Pusat Statistik Kota Bontang

Badan Pusat Statistik Kabupaten Paser, 2010, Kabupaten Paser Dalam Angka 2010, Tanah Grogot, Badan Pusat Statistik Kabupaten Paser

Badan Pusat Statistik Kabupaten Kutai Barat, 2010, Kutai Barat D a lam Angka 2010 , Sendawar, Badan Pusat Statistik Kabupaten Kutai Barat

Badan Pusat Statistik Kabupaten Kutai Kartanegara, 2010, Kutai Kartanegara Dalam Angka 2010, Tenggarong, Badan Pusat Statistik Kabupaten Kutai Kartanegara

Badan Pusat Statistik Kabupaten Malinau, 2010, Kabupaten Malinau Dalam Angka 2010, Malinau, Badan Pusat Statistik Kabupaten Malinau.

Badan Pusat Statistik Kabupaten Bulungan, 2010, Kabupaten Bulungan Dalam Angka 2010, Bulungan, Badan Pusat Statistik Kabupaten Bulungan.

Anggaran Pendidikan Capai 20 Persen, $\mathrm{s} \mathrm{u} \mathrm{m}$ b e $\mathrm{r}$ http://www.kaltimpost.co.id/i ndex.php/main/praca/account _manger_lokalizacja_poznan ?mib=berita.detail\&id $=4907$, diakses 25 september 2011

Visi dan Misi, sumber : http://dinkes.kutaikartanegara kab.go.id/id/visimisi.php, diakses 25 september 2011

Visi Dan Misi, sumber: http://www.kubarkab.go.id/pr ofil.php?id=4, diakses 25 september 2011

Kebijakan Umum, SDM sumber : http://www.kubarkab.go.id/ke bijakan.php?id=6, diakses 25 september 2011

Tahun ini pemkab alokasikan dana pendidikan $\mathrm{Rp} 208$ miliar, $\mathrm{s} \mathrm{u} \mathrm{m}$ b e $\mathrm{r}$ http://www.paserkab.go.id/pu blikasi/89, diakses 25 september 2011

Rencana Program Dan Kegiatan Indikatif, sumber : http://pendidikan.paserkab.go .id/c etak2.php? id=116, diakses 25 september 2011

Empat Belas Indikator Bontang $\mathrm{C}$ e r d a s, s u m b e r : http://www.kaltimpost.co.id/? $\mathrm{mib}=$ berita.detail\&id $=79334$, diakses 24 september 2011

Empat Belas Indikator Bontang Cerdas, sumber: http://www.kaltimpost.co.id/i ndex.php/main/praca/account manger_lokalizacja_poznan $\overline{\text { ?mib}}=$ berita.detail\&i $\overline{\mathrm{d}}=79334$ , diakses 24 september 2011 
42 Daerah Tak Dapat Dak Pendidikan, $\mathrm{s} \mathrm{u} \mathrm{m} \mathrm{b}$ e $\mathrm{r}$ http://djkd.depdagri.go.id/?je nis $=$ news $\& p=$ detail_berita\&i $\mathrm{d}=142 \& \mathrm{kd}=\mathrm{b}$, diakses 23 september 2011

Visi \& Misi Dinas Kesehatan Kota B o n t a n g, sumber : http://dinkes.bontangkota.go.i d/index.php/selayangpandang/visi-a-misi, diakses 23 september 2011

Visi Dinas Kesehatan Kota Balikpapan, $\mathrm{s} \mathrm{u} \mathrm{m} \mathrm{b}$ e $\mathrm{r}$ http://dkk.balikpapan.go.id/in dex.php?option $=$ com_content \&task=view\&id=26\&itemid $=$ 49 , diakses 23 september 2011

Jaminan Kesehatan Daerah : Saling Tolong Untuk Yang Sakit, sumber : http://www.dkinsufa.info/kesehatan/400jaminan-kesehatan-daerahsaling-tolong-untuk-yangsakit? lang=, diakses 22september 2011

Lima tahun, 7 ribu warga miskin dientaskan pendatang baru sumbang angka warga miskin sebanyak 3 ribu orang, sumber http://www.korankaltim.co.id/ $\mathrm{read} / \mathrm{news} / 2011 / 5651 /$, diakses 22 september 2011

Bab IV Strategi Pembangunan Daerah, RPJMD Kota Samarinda $2005-2010$ su mber: http://www.bappeda.samarind a.go.id/data/files/rpjm_04.pdf , diakses 22 september 2011
Visi \& Misi, sumber: http://disdik.balikpapan.go.id/ webdisdik/index.php/tentangkami/visi-a-misi ,diakses 22 september 2011

Anggaran Pendidikan Balikpapan Rp 420 Miliar, sumber : http://www.tempo.co/hg/pend idikan/2010/01/01/brk,20100 101-216713,id.html, diakses 21 september 2011

Alokasi Anggaran Pendidikan Turun R p 47 M, sumber: http://www.bappeda.samarind a.go.id/berita.php?id=142, diakses 21 September 2011

Visi dan Misi, sumber: http://disdik.kaltimprov.go.id/ visimisi.html, diakses 16 september 2011

Indeks Pembangunan Manusia, $\begin{array}{llllllll} & \mathrm{u} & \mathrm{m} & \mathrm{b} & \mathrm{e} & \mathrm{r} & \text { : }\end{array}$ http://Arsip.Tkpkri.Org/Indek $\mathrm{s}-\mathrm{P}$ e m b a $\mathrm{ng} \mathrm{u} \mathrm{n}$ a $\mathrm{n}$ Manusia.Html Tanggal 19 September 2011,. diakses 21 September 2011

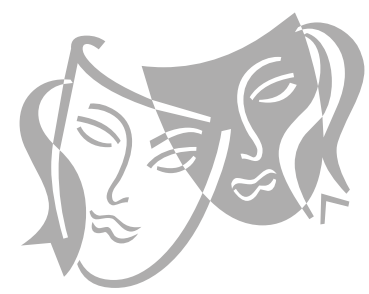

